\title{
Urban bird conservation: presenting stakeholder-specific arguments for the development of bird-friendly cities
}

\author{
Robbert PH Snep • Jip Louwe Kooijmans • Robert GM Kwak • Ruud PB Foppen • \\ Holly Parsons • Monica Awasthy • Henk LK Sierdsema • John M Marzluff • \\ Esteban Fernandez-Juricic • Jenny de Laet • Yolanda M van Heezik
}

(C) The Author(s) 2015. This article is published with open access at Springerlink.com

\begin{abstract}
Following the call from the United Nations Convention on Biological Diversity "Cities \& Biodiversity Outlook" project to better preserve urban biodiversity, this paper presents stakeholder-specific statements for bird conservation in city environments. Based upon the current urban bird literature we focus upon habitat fragmentation, limited habitat availability, lack of the native vegetation and vegetation structure as the most important challenges facing bird conservation in cities. We follow with an overview of the stakeholders in cities, and identify six main
\end{abstract}

R. P. Snep ( $\square)$

Alterra - Wageningen UR, P.O. 47, 6700 AA Wageningen, The Netherlands e-mail: robbert.snep@wur.nl

J. L. Kooijmans $・$ R. G. Kwak $\cdot$ R. P. Foppen

Birdlife Netherlands, P.O. Box 925, 3700 AX Zeist, The Netherlands

R. P. Foppen $\cdot$ H. L. Sierdsema

SOVON, Dutch Centre for Field Ornithology, PO Box 6521, 6503 GA Nijmegen, The Netherlands

H. Parsons

BirdLife Australia, 1 Jamieson St, Sydney Olympic Park, NSW 2127 Sydney, Australia

M. Awasthy

Department of Biological Sciences, Macquarie University, Sydney, Australia

J. M. Marzluff

School of Environmental and Forest Sciences, College of the Environment, University of Washington, Seattle, WA 98195, USA

E. Fernandez-Juricic

Department of Biological Sciences, Purdue University, West Lafayette, IN 47907, USA

J. de Laet

Groep Terec, Gent University, Ledeganckstraat 35, 9000 Ghent, Belgium

Y. M. van Heezik

Department of Zoology, University of Otago, P.O. Box 56, 9054 Dunedin, New Zealand

R. P. Foppen

Department of Animal Ecology and Ecophysiology, Institute of Water and Wetland Research, Radboud University, Nijmegen, The Netherlands 
groups having the greatest potential to improve bird survival in cities: i) urban planners, urban designers and (landscape) architects, ii) urban developers and engineers, iii) homeowners and tenants, iv) companies and industries, v) landscaping and gardening firms, vi) education professionals. Given that motivation to act positively for urban birds is linked to stakeholder-specific advice, we present ten statements for bird-friendly cities that are guided by an action perspective and argument for each stakeholder group. We conclude with a discussion on how the use of stakeholder-specific arguments can enhance and rapidly advance urban bird conservation action.

Keywords Urban bird conservation · Stakeholder · Argument · Conservation strategy · Urban biodiversity · Urban green

\section{Introduction}

In their recent paper called the Cities \& Biodiversity Outlook, the Convention on Biological Diversity (CBD), ICLEI (the local governments for sustainability), and the Stockholm Resilience Centre calls for action and policy to conserve urban biodiversity, maintain the ecological functioning of cities and offer citizens opportunities to experience and learn about local wildlife in cities worldwide (CBD 2012). "With the growing awareness of the value of biodiversity and ecosystem services, cities with rich native biodiversity should ensure that their biodiversity is conserved. Cities with impoverished biodiversity should pursue enhancement, restoration, and reintroduction efforts to increase native biodiversity" (p.25). Following this call, this paper presents a list of 10 statements and arguments - targeting different stakeholder groups - on why we should take steps to transform traditional city environments into more bird-friendly ones. Cities are complex socio-ecological systems (Moffatt and Kohler 2008) in which to roll out a traditional bird conservation programme (that targets only a small number of different stakeholder groups). They have mosaics of divergent land uses, with each land use having its own habitat quality for each bird species. Moreover, cities present a high multistakeholder environment, where people have different roles and stakes in different settings (CBD 2012; Teillac-Deschamps et al. 2009). An urban dweller can be a home-owner, an employee, a shopping mall client, a sportsman ... all the same person, but not at the same time. Further, bird conservation in cities is often not seen as a priority when the species themselves may be abundant and when many people feed birds in their gardens (Davies et al. 2009), spending millions of dollars annually to do so (Clucas et al. 2014). However, feeding birds is not the only conservation action that can be taken for birds in cities.

This paper aims to improve existing urban bird conservation practice by exploring ways of engaging people within their different roles by presenting arguments and action perspectives that are tailored to various urban stakeholder groups. These arguments are based upon the opportunities that various urban stakeholders may offer to conserve urban birds through the creation of essential habitat features (e.g., the provision of safe nesting places), whilst reducing urban threats, barriers and disturbances (e.g., reducing window collisions). Specifically, these opportunities vary from creating cohesive and robust green infrastructure planning and design (Tzoulas et al. 2007) to providing wildlife-friendly architecture and garden management. Sufficiently-sized and wellconnected green patches cities are necessary to accommodate a rich urban bird community (habitat quantity), but this must also occur in conjunction with proper green design and management to ensure there is also sufficient habitat quality. A variety of stakeholders must be including in order to achieve the habitat quality and quantity required for bird-friendly cities, from the direct ecological influencers (e.g. city park managers, garden owners) to the highly important but often missed city infrastructure influencers (e.g. planners, project developers, architects). 
This paper begins with a brief overview of the current value of cities as bird habitat and outlines the major challenges that urban environments may present for bird survival. We then identify the wide range of key stakeholders who play a vital role in ensuring and enhancing urban bird populations and their city habitat. Based upon each stakeholder's characteristics we present ten statements for bird-friendly cities that are guided by an action perspective and a specific argument for the key stakeholder. We conclude with a discussion on how the use of stakeholderspecific arguments can enhance and rapidly advance urban bird conservation action.

\section{The value and challenges that cities offer to birds: A brief summary}

Urban birds: Species richness, abundance, spatial dynamics and human experience

To create context for our call to better address the need for urban bird conservation, this section briefly summarizes the value of urban environments for birds, in terms of species richness, abundance, metapopulation dynamics and human experience.

Species richness Numerous studies have highlighted the high avian species richness of city environments (e.g. Donnelly and Marzluff 2004; Marzluff 2005), although most of these studies have focused upon a single, or very few cities. Aronson et al. (2014) compared the lists of birds recorded in 149 cities equally spread around the globe and found that $20 \%$ of all bird species have been recorded in cities. In some parts of the world that have a long history of urbanization, this proportion may be higher. In an overview of the breeding birds in European cities, Kelcey and Rheinwald (2005) showed that 272 bird species (including national Red List species) were observed in at least one of these 11 cities: Berlin, Bonn, Bratislava, Brussels, Florence, Hamburg, Lisbon, Lublin, Moscow, Prague, Rome, St. Petersburg, Sofia, Valencia, Vienna and Warsaw. Given that Hagemeijer and Blair (1997) identified a total of 495 breeding bird species in Europe (excluding the small number of non-breeding European bird species), the 272 bird species observed in cities constitute a substantial part (approximately $50 \%$ ) of the total bird species richness of Europe. In addition, a recent survey of 49 countries conducted by BirdLife International that 1.9 to $4.2 \%$ of all 10,500 bird species as currently described by science use city environments as prime habitat (Fergus et al. 2013).

Bird abundance Cities can also be important for the population numbers of certain species. One may expect that, in any given country, the proportion of bird species for which cities are the main habitat depends upon both the area of urban landscape and the age since urbanization, as well as the specific habitat characteristics of the urban area. For example, the Netherlands is a Western European country with a long history of urbanization, which has resulted in an urban area that covers $16 \%$ of the country's surface. For approximately one third of its breeding bird species ( 45 of the 151 species) the proportion of breeding pairs that settle in urban environments is higher than the actual proportion of the urban land cover (16\%). For 13 of the 151 breeding bird species the urban proportion of breeding pairs was even more than half of the national breeding population (Kwak and Louwe Kooijmans 2009). In this case, the urban environment appears to be a very important habitat. Unfortunately, similar statistics for most other countries are unknown. In the BirdLife International survey of urban birds, only $27 \%$ of participating countries $(n=49)$ have a dedicated monitoring scheme for urban birds (Fergus et al. 2013).

Spatial patterns and processes The variable habitat quality of city environments may affect population shifts in birds so that some populations grow, some decline and others remain stable 
in an interplay of source-sink dynamism (Oleyar 2011; Marzluff in review). Some studies suggest that urban habitats may act as sinks, recruiting birds from the city edge (e.g., van Heezik et al. 2010), while others classify city environments as suitable habitats for supporting passerine bird populations (e.g. Balogh et al. 2011).

Human experience of birds The world's human populations are becoming increasingly urbanised, with $78 \%$ of the inhabitants of the more developed nations and more than $50 \%$ of the global human population now living in or near cities (United Nations 2007). As a result, the vast majority of people will only experience nature and interactions with wildlife in cities. These interactions benefit both humans and wildlife, for example as people feed birds, they become more abundant, and this increased population may lead to more visibility of the birds by citizens and as such may, in turn, enhance human health and well-being (Clucas 2011; Clucas et al. 2011; Clucas and Marzluff 2012). With more people living in cities, conservation action is becoming increasingly dependent upon people's experiences with nature. In fact, wildlife interactions are argued to be just as important as conservation action itself (Fernández-Juricic and Jokimäki 2001; Savard et al. 2000). This is because enjoying birds in a garden or park may increase the support for bird conservation in cities (Goddard et al. 2013; Clucas et al. 2014) and perhaps concern for wildlife beyond the city.

Summarizing, urban environments:

- may accommodate a rich diversity of bird species (including endangered species),

- may contribute substantially as a prime habitat for at least some of these species,

- play a role within the overall metapopulation dynamics (source/sink/stable) of bird species at the regional or national scale (not studied for most species) or it appears species-specific (varies across studies of different species),

- have the potential to connect people to wildlife and nature, as the majority of the global human population now reside within cities.

Challenges for bird survival relate to both urban design and human activities

Despite the opportunities that cities present for some birds, urban environments are often un-ideal and challenging habitats for many (with feral pigeons as one of the few exceptions). The extent to which a bird experiences a city as an environment that provides good habitat, is the (mis)match between the bird's habitat preferences and the sum of human decisions to develop and use the city in a certain way (generally without having the bird's habitat preferences in mind). Based upon the literature, we prioritize the following challenges for bird survival in cities:

\section{1) Habitat fragmentation and availability}

Birds require sufficient and well-connected habitats to establish viable populations. In cities, habitat is fragmented and large suitable patches are lacking. This negatively impacts bird diversity and abundance (Donnelly and Marzluff 2004; Chace and Walsh 2006; MacGregor-Fors and Schondube 2011).

\section{2) Vegetation composition and structure}

Most bird species prefer a diverse vegetation structure with a multi-layer canopy of native plants (Lancaster and Rees 1979). Native vegetation supports significantly greater bird abundance, diversity, species richness, biomass, and breeding pairs of native species compared 
to urban patches with non-native vegetation (Burghardt et al. 2009). However, suburban landscapes, which make up a large proportion of the green space in cities, are generally composed of an abundance of open grass lawns and non-native (ornamental) trees and shrub.

\section{3) Predation and disturbance by pets}

Domestic cats are one of the biggest predators of urban birds, especially fledglings (Møller 2008; Møller and Ibáñez-Álamo 2012 ; Lowe et al. 2011), while domestic dogs are a source of nuisance (see next point).

\section{4) Human presence}

Although urban birds have developed a certain tolerance to human presence, people can still be considered a disturbing factor for birds that are foraging, nesting or resting. For example, frequently disturbed birds display greater vigilance behaviour thereby diminishing the time available for foraging (Fernández-Juricic and Tellería 2000).

\section{5) Buildings}

Older buildings historically offered nesting opportunities for birds under roofs (De Laet and Summers-Smith 2007). However, modern buildings are well-sealed to save energy, and therefore impenetrable to birds. In contrast to the positive aspects of providing habitat, buildings can also present hazards. For example, mirrored windows cause significant bird mortality (Klem et al. 2009).

Other factors that challenge bird survival in cities are road and rail traffic that result in fatal collisions (Ramp et al. 2006) and produce loud noise disabling song birds to defend their territory (Halfwerk et al. 2011; Schroeder et al. 2012), a surplus of artificial light (Faeth et al. 2011) and human waste (Ottoni et al. 2009), and the environmental pollution of air, soil, water (e.g., Kamiński 1998; Bonier 2012). Occasionally birds can adapt to the challenges cities provide and this response appears taxon-specific. For example, urban-dwelling great tits Parus major have been shown to sing at a higher pitch in order to reduce the masking effects of background urban noise on their song transmission (Slabbekoorn et al. 2012). However, these adaptations have a limited added value for the overall survival of birds and do not compensate for a lack of habitat quantity, connectivity and quality in cities - factors which have been identified as critical (Barbosa de Toledo et al. 2012; Kubantsev and Kolyakin 1995; Sierdsema et al. in review; Strohbach et al. 2013).

Overall, city environments present a challenging landscape for birds to survive and thrive. Although many species can already been found in cities, it is clear that 'being present' does not mean 'thriving'. There is a need to better conserve birds in cities, particularly if we want city environments to really contribute to overall bird conservation and wildlife experience.

\section{Identifying key stakeholders and arguments for urban bird conservation}

Urban environments present complex structure in both habitat and inhabitants. Unlike, for example, agricultural landscapes where there are a handful of stakeholders (e.g. farmers, water boards), urban environments consist of a greater variety and number of conservation participants such as land owners, institutions and associations (e.g. citizens, housing corporations, businesses, investors, sports clubs etc.). In addition, city development and management include an additional set of stakeholders and processes that are often ignored or simply not considered within urban conservation action plans. These city development professionals 
make countless choices that may be relevant for bird conservation, such as the position of vegetation and green space within plans, which tree species are planted, which building materials to use for roofs, and so on. A successful conservation strategy for urban birds should include the full range of stakeholders and identify the groups that are key for bird survival.

How do we even begin to map all the stakeholders in cities? Although several studies have identified the various stakeholders in relation to urban green or biodiversity in cities (e.g. Asikainen and Jokinen 2009; Azadi et al. 2011), no systematic approach currently exists in the literature. As a result, we created a new classification system. We began by categorising stakeholders to the different stages of the urbanization process: the development stage, the usage stage and the management stage. We then considered the general lay-out and structure of a city (the pattern). Six main categories were distinguished based on urban land use, each with its own set of stakeholders: (i) residential areas, (ii) business areas (including industry and shopping malls), (iii) utilities (e.g. schools, hospitals), the city's main (iv) green and (v) water infrastructure and (vi) the (rail)road infrastructure. Urban green, a major component of bird habitat, can be found in varying degrees within all urban land use types. Large urban green patches like parks, sporting fields and allotment gardens make part of the main green infrastructure. In the other urban land use types urban green is present at a smaller scale (e.g., in gardens, road verges, corporate green, river banks). Finally, we combined these two classifications into a matrix that present a broad range of identified stakeholders (Table 1).

From this stakeholder overview, and following the challenges for urban bird survival, we selected the stakeholder roles below as key for urban bird conservation. We base our selection on years of practical experience in urban bird conservation (e.g. by Birdlife International).

\section{A) Urban planners, urban designers and architects, and landscape architects}

These professionals, both in municipal and corporate service, shape the demand of land owners and local authorities into spatial zoning and design plans for residential, business, utility, green, water and infrastructure areas. They determine the city's physical layout and thus the overall availability and connectivity of urban green and water.

\section{B) Urban developers and engineers}

These professionals transform the designers' plans into man-made constructions.

\section{C) Homeowners and tenants}

These stakeholders predominantly determine the type, character and management of residential areas, including private gardens.

\section{D) Companies and industries}

These organisations are representatives for business and industrial areas, ports and office sites (including left-over land), in a similar way as the homeowners and tenants.

E) Landscaping and gardening firms

These stakeholders maintain both the public and private green space.

F) Education and communication staff 


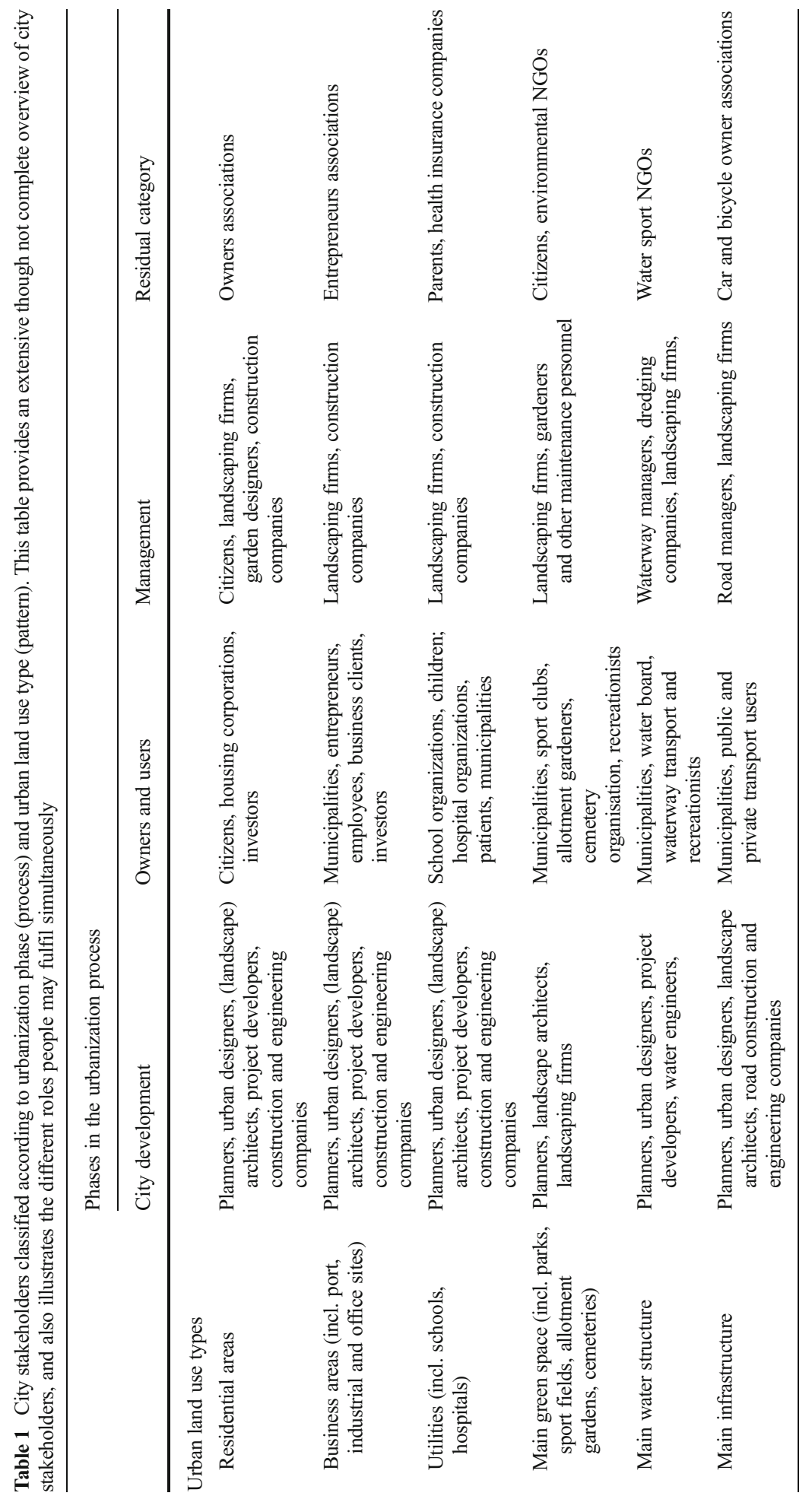


The current status of cities as bird habitats implies a need for more education and outreach in urban bird conservation (Miller 2005). Education and communication staff at schools and NGOs can fulfil this need.

Note on the role of governments as actors and regulators:

'Local governments' or 'municipalities' present a challenge for this stakeholder classification: these governmental bodies include a wide array of professional actors (planning, design, conservation, legal, economic, etc.), each with their own specialism and interests. Moreover, the role of local governments may vary largely among cities worldwide. In some cases they coordinate the city's design, development and management. In other cases with different governance practices the role of municipalities is much smaller. In this paper, we have chosen to only highlight the role of local governments in the planning and design of cities in our classification (see the group of professionals in this category). This is as in planning and design the role of local governments is unambiguous in cities worldwide and can obviously be linked with 'habitat fragmentation and availability', a main challenge for urban bird conservation.

In addition, the regulatory role that governments play is a key feature that distinguishes them from other urban actors. The ability to make and maintain regulations on every aspect of the city (e.g. from building codes to urban green space design) means that they have the potential to significantly impact the city environment for birds. In international city practice, there are examples of local governments that enforce within their building codes the actual greening of new developments (e.g. green roofs in Germany) and thus stimulate bird habitat development. However, local government can also provide regulations that discourage bird habitat development, for example, by decreeing the removal of shrubs from urban green space for social security reasons. In their book on urban wildlife management Adams et al. (2006) designate a whole chapter on the impact of federal, state, county, city and local laws and ordinances on wildlife conservation. Their extensive discussion only covers the impact of regulations on wildlife in U.S. cities. Incorporating the wide range of regulations which differ between countries and cities into this paper would be impossible. We therefore recognize the impact that regulations can have on urban bird conservation, but do not discuss them here.

Reaching the right city stakeholder with the right (conservation) argument

To improve the current state of urban bird conservation, we've looked to actual practices of nature conservation in cities. Goddard et al. (2013) illustrated that residents reveal a range of motivations for wildlife-friendly gardening. We expect a similar range among other stakeholders and practices other than just gardening. It has been suggested that taking into account the diversity of personal perceptions and practices, thereby providing a range of actions increases the success rate of participation (Teillac-Deschamps et al. 2009). In December 2011, at the International Congress on Conservation Biology (Auckland, New Zealand), the Birdlife International Group on Urban Birds (BIG-UB) organized a symposium and workshop to discuss the current state of art in urban bird science and conservation. Participants included urban bird scholars, conservationists and practitioners from different parts of the world, and with extensive cooperation with the identified stakeholder groups in urban bird conservation. With this group of bird and city practice experts, we formulated ten statements emphasizing the need for increased attention on the challenges and opportunities in urban bird conservation that are specifically linked to key stakeholders and address different perceptions on conservation (Table 2). Based upon the literature and practical experience, we provide for each statement an action perspective as well as a main argument for the key stakeholder that stress the mutual benefit gained for both humans and birds. 


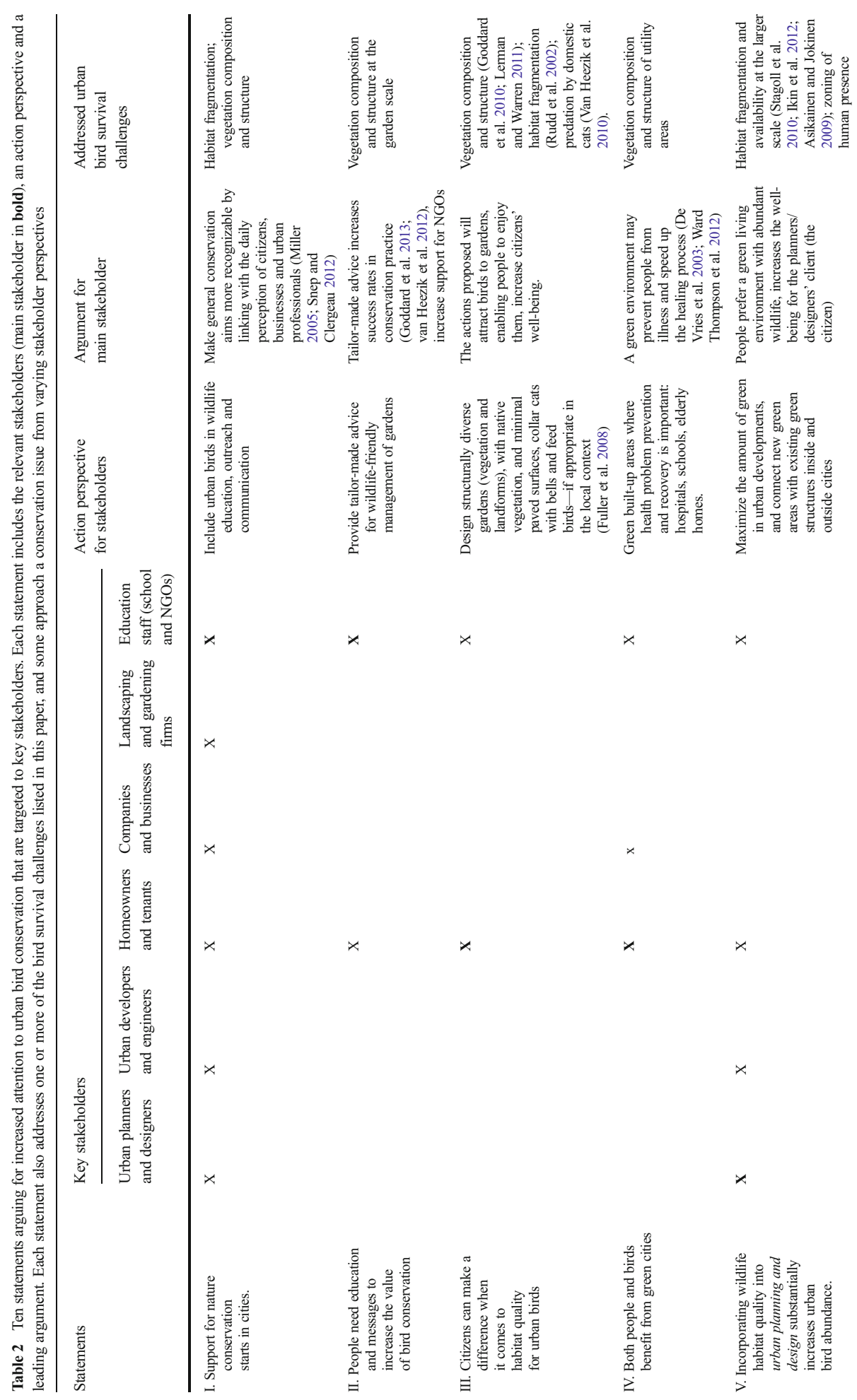




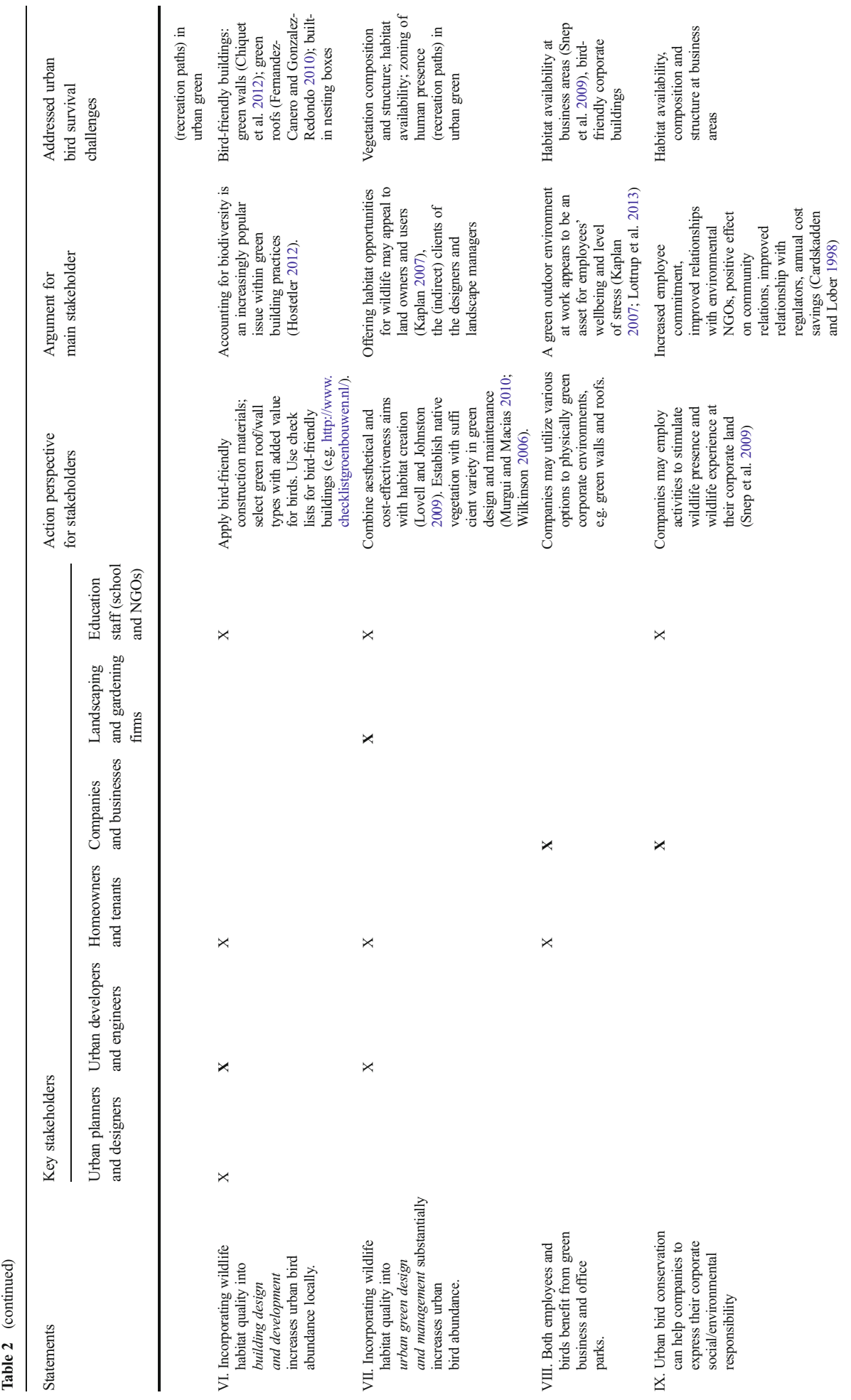




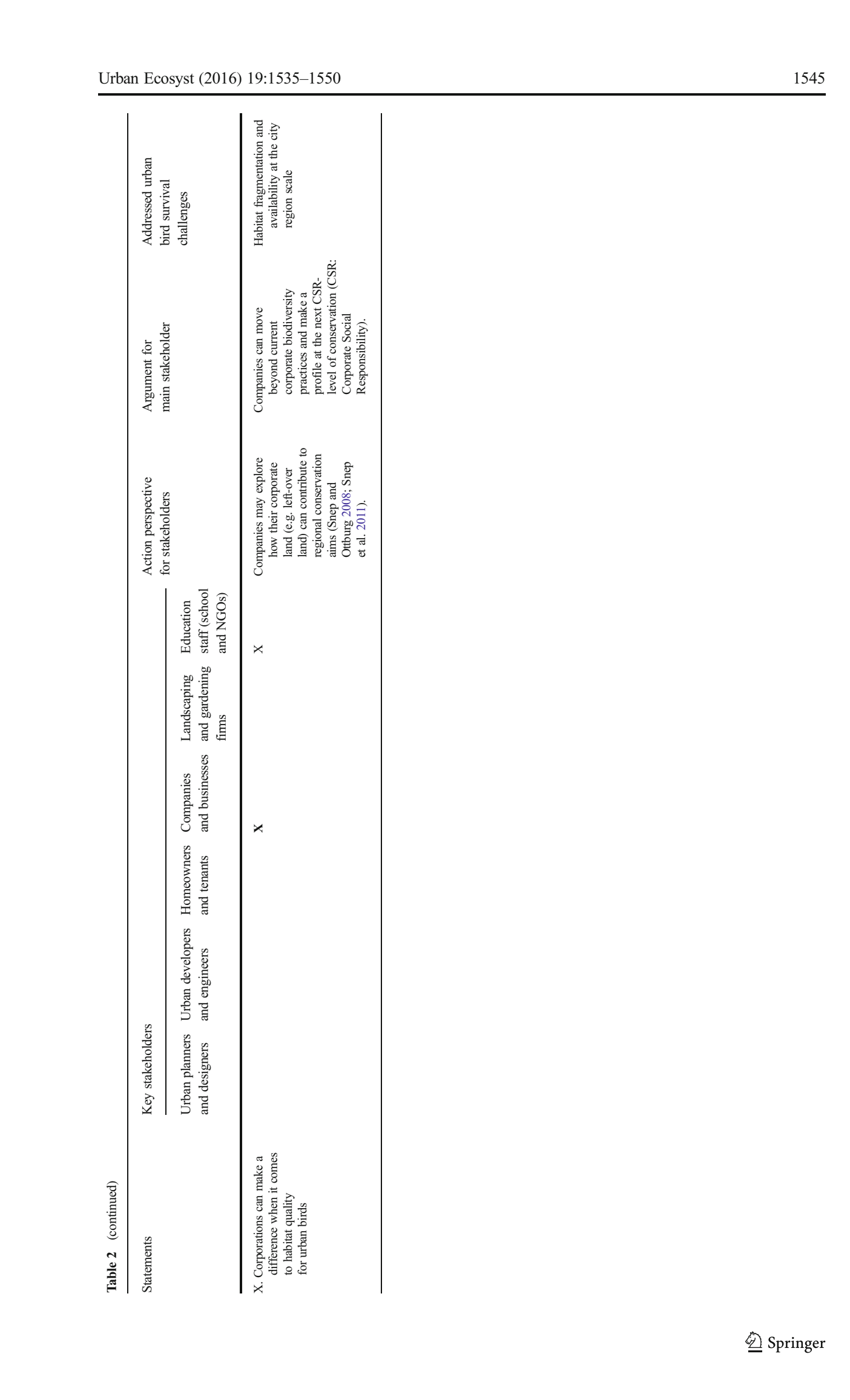


Our overview (Table 2) can be used to inform conservationists and governments about the wide range of actors that all may contribute to urban bird conservation. It provides targeted arguments and action perspectives for each stakeholder that can be used to inform action. Given that the practical approach to implementing these suggestions may vary between countries and cities, we suggest the incorporation of communication experts in any future discussions. We emphasize the importance of stakeholder-specific arguments instead of one general message.

\section{Discussion}

Momentum for urban bird conservation

If urban bird conservation is to be considered a serious part of bird conservation worldwide, conservation efforts must be more strategic and less non-committal than current practices in most cities (Fergus et al. 2013). As in nature reserves, conservation aims in the urban landscape should be focused on maintaining bird species diversity and preventing vulnerable populations from local extinction. Some countries have taken the step to appoint Important Bird and Biodiversity Areas (IBBA) within urban areas, although there is still a majority of countries and cities that lack an urban bird conservation program (Fergus et al. 2013). With on-going urbanization and an increasing global human population that consists predominantly of urban dwellers, it seems to be the right moment to more prominently address urban biodiversity conservation (CBD 2012), including birds. Scientific studies offer a plethora of evidence to consider urban birds worthy of conservation. The next issue then is how to achieve such ambitious goals in a built-up landscape that is not considered, and managed, as an ecosystem.

In this paper we provided an overarching perspective on how the many challenges that birds face in cities could be overcome by taking into consideration all landscape classification types and including the various stakeholders and participants in urban conservation programs. Cities are crowded places where people live and work in a landscape composed of buildings, roads, green space and water. Without human activities they would be ghost cities and without man-made structures it's simply a group of people conducting activities in a non-urban environment (e.g. in a natural area). In both cases there still will be an impact on the birds' habitat. However, it is the combination of urban design and human activities that really defines how a city environment is experienced by birds. The challenges for urban bird survival as mentioned in this paper originate from both categories. Based on literature (e.g. Marzluff 2005) we however consider habitat fragmentation and availability, and vegetation composition and structure to have the highest impact on the suitability of cities as bird habitat. The habitat fragmentation challenge must be addressed from a city-wide scale down to the neighbourhood level and the vegetation structure challenge from the neighbourhood down to the building level. For each of these challenges, the right decision taken by the right stakeholder could mean a lot in terms of bird-friendliness of a city. The right decisions concern connecting habitats and providing sufficient habitat area (planning) as well as designing and maintaining urban green spaces in a wildlife-friendly manner (design). As illustrated by Table 2, the right stakeholder in this case means that all six key stakeholder groups could make a contribution. However, the conservation policy and expertise of local governments 
here play a crucial role. Other challenges we mentioned could be more easily assigned to one or few key stakeholders. For example, predation by domestic cats is primarily linked to homeowners and tenants, and education professionals. The ten statements for urban bird conservation listed here illuminate the triangle relationship of 'city stakeholder-urban land use-birds' from various angles. By providing these arguments with concrete action perspectives and leading arguments for the main stakeholder we have provided an overarching view on how to transform urban landscapes into birdfriendly cities.

A new approach to urban bird conservation?

Our approach centres on the notion that cities are multi-stakeholder and multi-land use environments as such a complex socio-ecological system as the city requires more than a straight-forward conservation approach. However most publications on urban bird conservation list conservation measures derived from the bird's needs rather than offering a conservation strategy that shows insights in the underlying socio-economic drivers required for the transformation towards bird-friendly cities. Marzluff (2005) linked actions for bird conservation to specific stakeholders. Fernández-Juricic and Jokimäki (2001) discussed how from a landscape ecological point of view the right decisions in urban development could support urban birds. Whilst they mention several stakeholder groups, they did not elaborate how to motivate these stakeholders to really take action for urban birds. In fact, only a few studies have looked into socio-economic drivers that could support urban bird conservation. Lerman et al. (2012) analysed how residents may contribute to urban bird conservation by a wildlife-friendly design of their gardens, and determined different attitudes and practices among different socio-economic groups. Residents' motivations towards birdfeeding were described in various studies (Gaston et al. 2007; Davies et al. 2009; Clucas and Marzluff 2012) and a recent study by Goddard et al. (2013) discussed drivers and barriers for citizens to manage their gardens in a wildlife-friendly way. They addressed the oft-cited barrier of a lack of knowledge but stressed the importance of ' got to want to know'. Several studies have also illustrated the failure of top-down planning to incentivise behaviour change in residents of new 'green' or sustainable developments (Youngentob and Hostetler 2005; Hostetler and Noiseux 2010). According to Goddard et al. (2013), communicating information to the public is most successful when it involves a two-way process of dialogue and advice is tailored to the individual householder rather than a one-size fits all solution. They refer to the successful practice at Dunedin, New Zealand (Van Heezik et al. 2012) as a case study.

Altogether, this paper contributes to existing literature by presenting an overarching approach that interconnects urban land use, stakeholder groups and urban bird survival challenges at different scales, as well as providing statements, action perspectives and concrete arguments for each key stakeholder. However this paper also makes many generalizations due to its large scope and therefore cannot incorporate all details related the rich diversity among urban bird species and their ecology across the globe. We are also writing this paper from the perspective of the western practice in which offering sufficient space for green and water makes part of the urban development planning and design tradition. In other parts of the world, city development may be less planned, and urban bird conservation therefore has a lower priority when it comes to ensuring the health and wellbeing of residents. We therefore acknowledge the 
need to fine-tune conservation programmes at a country or culture specific level, and thus consider this study as a first step in the transformation towards bird-friendly cities.

Acknowledgments In December 2011, at the International Congress on Conservation Biology (Auckland, New Zealand), the Birdlife International Group on Urban Birds (BIG-UB) organized a symposium and workshop to discuss the current state in urban bird science, education and conservation. Participants included urban bird scholars, conservationists and practitioners from different parts of the world. This paper was based upon the outcome of that meeting. We hereby want to thank all participants for their input. Thanks also to Birdlife Netherlands for funding this paper.

Open Access This article is distributed under the terms of the Creative Commons Attribution License which permits any use, distribution, and reproduction in any medium, provided the original author(s) and the source are credited.

\section{References}

Adams CE, Lindsey KJ, Ash SJ (2006) Urban wildlife management. Taylor and Francis Group, Boca Raton Aronson MFJ, Sorte FAL, Nilon CH, Katti M, Goddard MA, Lepczyk CA, Warren PS, Williams NSG, Cilliers S, Clarkson B, Dobbs C, Dolan R, Hedblom M, Klotz S, Kooijmans JL, Kühn I, MacGregor-Fors I, McDonnell M, Mörtberg U, Pyšek P, Siebert S, Sushinsky J, Werner P, Winter M (2014) A global analysis of the impacts of urbanization on bird and plant diversity reveals key anthropogenic drivers. Proc R Soc B 281:20133330. doi:10.1098/rspb.2013.3330

Asikainen E, Jokinen A (2009) Future natures in the making: implementing biodiversity in suburban land-use planning. Plan Theory Pract 10(3):351-368

Azadi H, Ho P, Hafni E, Zarafshani K, Witlox F (2011) Multi-stakeholder involvement and urban green space performance. J Environ Plan Manag 54(6):785-811

Balogh AL, Ryder TB, Marra PP (2011) Population demography of Gray Catbirds in the suburban matrix: sources, sinks and domestic cats. J Ornithol 152(3):717-726

Barbosa de Toledo MC, Donatelli RJ, Batista GT (2012) Relation between green spaces and bird community structure in an urban area in Southeast Brazil. Urban Ecosyst 15(1):111-131

Bonier F (2012) Hormones in the city: endocrine ecology of urban birds. Horm Behav 61(5):763-772

Burghardt KT, Tallamy DW, Gregory Shriver W (2009) Impact of native plants on bird and butterfly biodiversity in suburban landscapes. Conserv Biol 23(1):219-224

Cardskadden H, Lober DJ (1998) Environmental stakeholder management as business strategy: the case of the corporate wildlife habitat enhancement programme. J Environ Manag 52(2):183-202

CBD - Secretariat of the Convention on Biological Diversity (2012) Cities and biodiversity outlook. Montreal, 64 pages. Available online http://cbobook.org/pdf/2013_CBO_Action_and_Policy.pdf

Chace JF, Walsh JJ (2006) Urban effects on native avifauna: a review. Landsc Urban Plan 74(1):46-69

Chiquet C, Dover JW, Mitchell P (2012) Birds and the urban environment: the value of green walls. Urban Ecosyst 16(3):453-462

Clucas BMJ (2011) Coupled relationships between humans and animals in urban areas. In: Niemela J (ed) Handbook of urban ecology. Oxford University Press, Oxford, pp 135-147

Clucas B, Marzluff JM (2012) Attitudes and actions toward birds in urban areas: human cultural differences influence bird behavior. Auk 129(1):8-16

Clucas B, Marzluff JM, Kübler S, Meffert P (2011) New directions in urban avian ecology: reciprocal connections between birds and humans in cities. In: Perspectives in urban ecology. Springer, Berlin, pp 167-195

Clucas B, Rabotyagov S, Marzluff JM (2014) How much is that birdie in my backyard? A cross-continental economic valuation of native urban songbirds. Urban Ecosyst. doi:10.1007/s11252-014-0392-X

Davies ZG, Fuller RA, Loram A, Irvine KN, Sims V, Gaston KJ (2009) A national scale inventory of resource provision for biodiversity within domestic gardens. Biol Conserv 142(4):761-771

De Laet J, Summers-Smith JD (2007) The status of the urban house sparrow Passer domesticus in north-western Europe: a review. J Ornithol 148(S2):275-278

de Vries S, Verheij RA, Groenewegen PP, Spreeuwenberg P (2003) Natural environments - healthy environments? An exploratory analysis of the relationship between greenspace and health. Environ Plan A 35(10):1717-1731 
Donnelly R, Marzluff JM (2004) Importance of reserve size and landscape context to urban bird conservation. Conserv Biol 18(3):733-745

Faeth SH, Bang C, Saari S (2011) Urban biodiversity: patterns and mechanisms. Ann N Y Acad Sci 1223:69-81

Fergus R, Louwe Kooijmans J, Kwak RGM (2013) Birdlife international global survey on the status of urban bird conservation. Birdlife International, Cambridge

Fernandez-Canero R, Gonzalez-Redondo P (2010) Green roofs as a habitat for birds: a review. J Anim Vet Adv 9(15):2041-2052

Fernández-Juricic E, Jokimäki J (2001) A habitat island approach to conserving birds in urban landscapes: case studies from southern and northern Europe. Biodivers Conserv 10(12):2023-2043

Fernández-Juricic E, Tellería JL (2000) Effects of human disturbance on spatial and temporal feeding patterns of Blackbird Turdus merula in urban parks in Madrid, Spain. Bird Study 47(1):13-21

Fuller RA, Warren PH, Armsworth PR, Barbosa O, Gaston KJ (2008) Garden bird feeding predicts the structure of urban avian assemblages. Divers Distrib 14(1):131-137

Gaston KJ, Fuller RA, Loram A, MacDonald C, Power S, Dempsey N (2007) Urban domestic gardens (XI): variation in urban wildlife gardening in the United Kingdom. Biodivers Conserv 16(11):3227-3238

Goddard MA, Dougill AJ, Benton TG (2010) Scaling up from gardens: biodiversity conservation in urban environments. Trends Ecol Evol 25(2):90-98

Goddard MA, Dougill AJ, Benton TG (2013) Why garden for wildlife? Social and ecological drivers, motivations and barriers for biodiversity management in residential landscapes. Ecol Econ 86:258-273

Hagemeijer WJ, Blair MJ (1997) The EBCC atlas of European breeding birds: their distribution and abundance. T. \& AD Poyser, London

Halfwerk W, Bot S, Buikx J, Van Der Velde M, Komdeur J, Ten Cate C, Slabbekoorn H (2011) Low-frequency songs lose their potency in noisy urban conditions. Proc Natl Acad Sci U S A 108(35):14549-14554

Hostetler ME (2012) The green leap: a primer for conserving biodiversity in subdivision development. University of California Press, Berkeley

Hostetler M, Noiseux K (2010) Are green residential developments attracting environmentally savvy homeowners? Landsc Urban Plan 94(3):234-243

Ikin K, Knight E, Lindenmayer DB, Fischer J, Manning AD (2012) Linking bird species traits to vegetation characteristics in a future urban development zone: implications for urban planning. Urban Ecosyst 15(4): 961-977

Kamiński P (1998) The impact of Ca and heavy metals upon the nest development of sparrows (Passer spp.) and other synanthropic birds. Pol J Environ Stud 7(2):53-64

Kaplan R (2007) Employees' reactions to nearby nature at their workplace: the wild and the tame. Landsc Urban Plan 82:17-24

Kelcey JG, Rheinwald G (2005) Birds in European cities. Ginster Verlag St. Katharinen, Germany

Klem D, Farmer CJ, Delacretaz N, Gelb Y, Saenger PG (2009) Architectural and landscape risk factors associated with bird-glass collisions in an urban environment. Wilson J Ornithol 121(1):126-134

Kubantsev B, Kolyakin N (1995) Spatial differentiation of the animal component in industrial urban ecosystems. Russ J Ecol 26(2):121-125

Kwak RGM, Louwe Kooijmans J (2009) Urban bird trends in the Netherlands ('Stadsvogelbalans'). The Dutch Partner of Birdllife International, Zeist

Lancaster RK, Rees WE (1979) Bird communities and the structure of urban habitats. Can J Zoolog 57:2358-2368

Lerman SB, Warren PS (2011) The conservation value of residential yards: linking birds and people. Ecol Appl 21(4):1327-1339

Lerman SB, Warren PS, Gan H, Shochat E (2012) Linking foraging decisions to residential yard bird composition. PLoS ONE 7(8)

Lottrup L, Grahn P, Stigsdotter UK (2013) Workplace greenery and perceived level of stress: benefits of access to a green outdoor environment at the workplace. Landsc Urban Plan 110(1):5-11

Lovell ST, Johnston DM (2009) Creating multifunctional landscapes: how can the field of ecology inform the design of the landscape? Front Ecol Environ 7(4):212-220

Lowe KA, Taylor CE, Major RE (2011) Do common Mynas significantly compete with native birds in urban environments? J Ornithol 152(4):909-921

MacGregor-Fors I, Schondube JE (2011) Gray vs. green urbanization: relative importance of urban features for urban bird communities. Basic Appl Ecol 12(4):372-381

Marzluff JM (2005) Island biogeography for an urbanizing world: how extinction and colonization may determine biological diversity in human-dominated landscapes. Urban Ecosyst 8(2 SPEC. ISS):157-177

Marzluff JM (in review) Fostering resilient avifaunas by sustaining the connections between humans and nature along gradients of urbanization. Urban Ecosyst

Miller JR (2005) Biodiversity conservation and the extinction of experience. Trends Ecol Evol 20(8):430-434 
Moffatt S, Kohler N (2008) Conceptualizing the built environment as a social-ecological system. Build Res Inf 36:248-268

Møller AP (2008) Flight distance of urban birds, predation, and selection for urban life. Behav Ecol Sociobiol 63(1):63-75

Møller AP, Ibáñez-Álamo JD (2012) Escape behaviour of birds provides evidence of predation being involved in urbanization. Anim Behav 84(2):341-348

Murgui E, Macias A (2010) Changes in the House Sparrow Passer domesticus population in Valencia (Spain) from 1998 to 2008. Bird Study 57(3):281-288

Oleyar MD (2011) Urbanization influences on songbird population dynamics, community structure, and energy relationships. University of Washington

Ottoni I, de Oliveira FFR, Young RJ (2009) Estimating the diet of urban birds: the problems of anthropogenic food and food digestibility. Appl Anim Behav Sci 117(1-2):42-46

Ramp D, Wilson VK, Croft DB (2006) Assessing the impacts of roads in peri-urban reserves: road-based fatalities and road usage by wildlife in the Royal National Park, New South Wales, Australia. Biol Conserv 129(3):348-359

Rudd H, Vala J, Schaefer V (2002) Importance of backyard habitat in a comprehensive biodiversity conservation strategy: a connectivity analysis of urban green spaces. Restor Ecol 10(2):368-375

Savard JPL, Clergeau P, Mennechez G (2000) Biodiversity concepts and urban ecosystems. Landsc Urban Plan 48(3-4):131-142

Schroeder J, Nakagawa S, Cleasby IR, Burke T (2012) Passerine birds breeding under chronic noise experience reduced fitness. PLoS ONE 7(7)

Sierdsema HLK, Kampichler C, Louwe Kooijmans J, Schoppers J, Kwak RGM (in review) Benchmarking urban bird habitats - a new way of promoting wildlife conservation in built-up areas. Urban Ecosyst

Slabbekoorn H, Yang XJ, Halfwerk W (2012) Birds and anthropogenic noise: singing higher may matter: (A Comment on Nemeth and Brumm, "Birds and Anthropogenic Noise: Are Urban Songs Adaptive?"). Am Nat 180(1):142-145

Snep RPH, Clergeau P (2012) Biodiversity in cities, reconnecting humans with nature. In: Loftness VH, Haase D (eds) Sustainable built environments. Springer, New York

Snep RPH, Ottburg FGWA (2008) The 'habitat backbone' as strategy to conserve pioneer species in dynamic port habitats: Lessons from the natterjack toad (Bufo calamita) in the Port of Antwerp (Belgium). Landsc Ecol 23(10):1277-1289

Snep R, Van Ierland E, Opdam P (2009) Enhancing biodiversity at business sites: what are the options, and which of these do stakeholders prefer? Landsc Urban Plan 91(1):26-35

Snep RPH, WallisDeVries MF, Opdam P (2011) Conservation where people work: a role for business districts and industrial areas in enhancing endangered butterfly populations? Landsc Urban Plan 103(1):94-101

Stagoll K, Manning AD, Knight E, Fischer J, Lindenmayer DB (2010) Using bird-habitat relationships to inform urban planning. Landsc Urban Plan 98(1):13-25

Strohbach MW, Lerman SB, Warren PS (2013) Are small greening areas enhancing bird diversity? Insights from community-driven greening projects in Boston. Landsc Urban Plan 114:69-79

Teillac-Deschamps P, Lorrillière R, Servais V, Delmas V, Cadi A, Prévot-Julliard AC (2009) Management strategies in urban green spaces: models based on an introduced exotic pet turtle. Biol Conserv 142(10): 2258-2269

Tzoulas K, Korpela K, Venn S, Yli-Pelkonen V, Kazmierczak A, Niemela J, James P (2007) Promoting ecosystem and human health in urban areas using Green Infrastructure: a literature review. Landsc Urban Plan 81:167-178

United Nations (2007) World urbanisation prospects: the 2007 revision population database. United Nations, New York

van Heezik Y, Smyth A, Adams A, Gordon J (2010) Do domestic cats impose an unsustainable harvest on urban bird populations? Biol Conserv 143(1):121-130

van Heezik YM, Dickinson KJM, Freeman C (2012) Closing the gap: communicating to change gardening practices in support of native biodiversity in urban private gardens. Ecol Soc 17(1):34

Ward Thompson C, Roe J, Aspinall P, Mitchell R, Clow A, Miller D (2012) More green space is linked to less stress in deprived communities: evidence from salivary cortisol patterns. Landsc Urban Plan 105(3):221-229

Wilkinson N (2006) Factors influencing the small-scale distribution of House Sparrows Passer domesticus in a suburban environment. Bird Study 53:39-46

Youngentob K, Hostetler M (2005) Is a new urban development model building greener communities? Environ Behav 37(6):731-759 